\title{
KERAGAMAN MANUSIA DALAM PENDIDIKAN ISLAM
}

\author{
M. Fathi Halimi \\ fathihalimi10@gmail.com \\ (Fakultas Agama Islam, Universitas Muhammadiyah Tangerang)
}

\begin{abstract}
Abstrak
Islam secara normatif telah menguraikan tentang kesetaraan dalam bermasyarakat yang tidak mendiskriminasikan kelompok lain. Islam memandang segala perbedaan sebuah anugrah Tuhan yang begitu besar yang harus di syukuri. Dalam tatanan kehidupan masyarakat multikulturalis dalam pandangan Islam memiliki kedudukan yang sama, memiliki hak dan kewajiban yang sama baik dalam bidang sosial, politik maupun hukum. Pendidikan memegang peranan penting. Pendidikan dalam hidup dan kehidupan manusia diakui sebagai satu kesatuan, proses pendidikan di masyarakat juga turut mempengaruhi perkembangan kepribadian manusia itu sendiri.
\end{abstract}

\section{Kata kunci: Keragaman, Manusia dan Pendidikan Islam}

\section{A. Pendahuluan}

Manusia makhluk ciptaan Allah SWT. Makhluk (Arab = ciptaan), sedangkan yang mencipta disebut khaliq. Dalam al-Qur'an disebutkan bahwa manusia diciptakan oleh Allah,"Bacalah dengan nama Tuhanmu yang telah menciptakan kamu dari segumpal darah" (QS. al 'Alaq [96] : 1-2)'. Secara rinci sulit ditemukan dalam al Quran tentang penciptaan Adam ${ }^{2}$. Akan tetapi yang

\footnotetext{
${ }^{1}$ Ayat-ayat al Quran yang disebutkan di dalam makalah ini, terjemahannya bersumber pada Kementerian Agama RI, Al Quran dan Tejemahnya, (Jakarta: Ditjen Bimas Islam, 2012. Sedangkan pengelompokan ayat-ayat yang berkaitan dengan manusia bersumber pada, Sukmajaya Asyarie dan Rony Yusyuf, Indek Al Quran, (Bandung: Pustaka, 1999). Lihat juga, Choirudin Hadhiri, Klasifikasi Kandungan Al Quran, (Jakarta: Gema Insani Press, 2002). Lihat juga, Syaikh Abdul Baqi, al Mu'jam al Mufahras li Alfadzil Quran, (Kairo: Dar al Hadis al Azhar, 1997). Dalam penyebutan sumber ayat ditulis nama surat, koma, lantas diberikan kode Q.S. (Quran Surat) ke berapa (menggunakan angka arab), titik dua, dan ditunjukkan ayat berapa (juga menggunakan angka arab).

${ }^{2}$ Berbagai pendapat tentang Adam, apakah manusia pertama atau bukan, masih diperdebatkan kalangan.
}

banyak disampaikan Allah adalah tentang penciptaan manusia dalam arti reproduksi secara makro. Hal ini bisa dilihat dalam surat al Hajj, QS. 22 : 5), Fathir, QS. 35 : 11), al Zumar, QS. 39 : 6, al Mukmin, QS. $40: 67$, dan sebagainya.

Di tinjau dari segi kebudayaan, manusia memiliki keragaman suku bangsa yang merupakan sumber kebudayaan nasional negara yang bersangkutan. Suku bangsa itu sendiri adalah suatu kelompok masyarakat yang terikat kesatuan budaya, bahasa, dan tempat tinggal. Oleh karena itu, setiap suku bangsa memiliki bahasa yang berbeda, tradisi dan kebudayaannya juga berbeda.

Keragaman merupakan suatu keniscayaan dalam kehidupan masyarakat. Keragaman seperti itu ada pada suku bangsa, agama, ras, serta budaya. Keragaman yang ada di Indonesia, misalnya, adalah kekayaan bangsa indonesia. Karena itu Pendidikan harus bisa mendorong keberagaman tersebut menjadi suatu kekuatan untuk bisa mewujudkan persatuan dan kesatuan nasional menuju indonesia yang lebih baik. 


\section{B. Memahami Manusia}

Manusia sebagai animal rasional, hayawanun natiq, hewan berpikir. Mereka yang menitikberatkan pada pembawaan kodrat manusia hidup bermasyarakat memberikan pengertian tentang manusia sebagai zoon politicon, homo socius, mahkluk sosial.

Orang yang menitikberatkan pada adanya usaha manusuia untuk mencukupi kebutuhan hidup, bahwa manusia adalah homo economicus, mahluk ekonomi. Bagi orang yang menitik beratkan manusia dalam menggunakan simbul-simbul memberi pengertian bahwa manusia adalah animal symboliticum ${ }^{3}$. Ada juga yang menitik beratkan pengertian manusia sebagai khalifh fi al ardh. ${ }^{4}$ Dalam salah ayat al Quran manusia digambarkan:

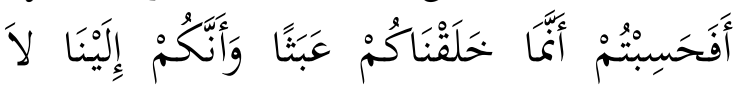

$$
\text { تُرْجَعُونَ (المؤمنون: } 0 \text { (1) }
$$

Maka Apakah kamu mengira, bahwa sesungguhnya Kami menciptakan kamu secara main-main (saja), dan bahwa kamu tidak akan dikembalikan kepada kami? (QS. Al-Mukminun [23]: 115).

Ayat di atas dapat dipahami bahwa terdapat tiga penegasan Allah SWT, yaitu 1) manusia adalah mahluk ciptaan Allah, 2) manusia diciptakan tidak sia-sia, tetapi berfungsi, 3)manusia akhirnya akan dikembalikan kepada Allah untuk mempertanggung jawabkan semua perbuatannya sewaktu hidup di dunia, dan perbuatan itu merupakan realisasi dari fungsi manusia itu sendiri ${ }^{5}$.

${ }^{3}$ Cassirer, dalam, Yusran Razak dan Tohirin, ed, Pendidikan Agama Islam untuk Perguruan Tinggi dan Umum, (Jakarta: Uhamka Press, 2011), h. 1 .

${ }^{4}$ Azhar Basyir, Falsafah Ibadah dalam Islam, (Yogayakarta: Pusat UII, 1984), h. 7. Lihat juga, al Baqarah, QS. 2: 30.

${ }^{5}$ Azhar Basyir, Op. Cit., 32.
Morteza Mutahari sebagaimana dikutip Yunan Yusuf, manusia adalah mahluk serba dimensi. Dimensi pertama, manusia tidak ubahnya seperti hewan, yang membutuhkan makan, minum, istirahat dan menikah, supaya tetap hidup, tumbuh dan berkembang. Dimensi kedua, manusia memiliki berbagai emosi yang bersifat etis, yaitu ingin memperoleh keuntungan dan menghindari kerugian. Dimensi ketiga, manusia memiliki komitmen kepada keindahan. Dimensi keempat, manusia memiliki dorongan untuk mengabdi dan menyembah Allah $\mathrm{SWT}^{6}$.

Seperti yang telah diketahui, kelebihan manusia dari makhluk-makhluk hidup lainya yaitu adanya akal-pikiran yang berkembang dan dapat dikembangan. Manusia dapat mendidik diri sendiri, dan dengan sengaja ia juga dapat mendidik orang lain, sehinggga kemampuan intelektualnya semakin berkembang. Umat manusia dengan akal-pikiran dan kebudayaannya senantiasa mengalami perkembangan serta kemajuan. Sebagaimana telah dikatakan bahwa manusia adalah mahluk dinamis. Dinamikanya tidak pernah berhenti, tetap aktif. Inilah yang memadukan manusia dengan sesamanya dan lingkungannya, yang akan tetap tumbuh berkembang selama masa hidupnya ${ }^{7}$.

\section{Identifikasi Manusia}

Ada beberapa pendekatan jika mempelajari manusia, di antaranya adalah, pertama, orang dapat menyelidiki manusia dalam hakikatnya yang murni dan esensial. Pendekatan ini sering dilakukan oleh para filosof. Kedua, orang dapat menyelidiki manusia dari sisi ideologis dan spiritual yang mengatur tindakan manusia dan yang

\footnotetext{
${ }^{6}$ M. Yunan Yusuf, dkk, Aqidah, (Jakarta: IKIP Muhammadiyah, 1999), h. 7.

${ }^{7}$ Anak Agung, Konseling Lintas Budaya, (Yogyakarta: Graha ilmu 2013), h. 32.
} 
mempengaruhi pembentukan personalitasnya. Ketiga, mengambil konsep tentang manusia dari penyelidikan-penyeldikan lembaga-lembaga etika dan yuridis yang telah terbentuk dari pengalaman sejarah dan kemasyarakatan. Keempat, manusia juga dapat diselideiki dengan pendekatan biologisnya $^{8}$.

Manusia, ditinjau dari konsepsi al Quran disebut dengan kalimat-kalimat: basyar, insan, dan al nas. Tuhan menggunakan kalimat "basyar" dalam al Quran, di antaranya ialah:

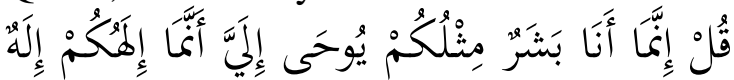

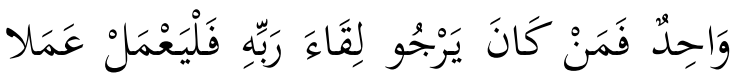

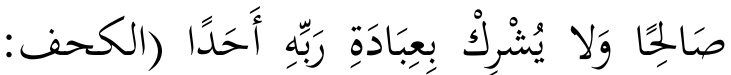

(1)

Katakanlah: "Sesungguhnya aku ini manusia biasa seperti kamu, yang diwahyukan kepadaku: "Bahwa sesungguhnya Tuhan kamu itu adalah Tuhan yang Esa". Barangsiapa mengharap perjumpaan dengan Tuhannya, maka hendaklah ia mengerjakan amal salih dan janganlah ia mempersekutukan seorangpun dalam beribadat kepada Tuhannya" (QS. Al Kahfi [18]: 110).

Sifat manusia sebagai basyar ini selalu dihubungkan dengan sifat-sifat biologisnya, karena itu sering disebut sebagai "human being" (manusia sekedar ada). Sebagai human being, wajar kalau muncul dari padanya sifat-sifat statis seperti halnya yang terdapat pada hewan.

Sedangkan manusia yang disebut dengan kalimat insan oleh al Quran, di antara firman-Nya adalah: "Demi (buah) Tin dan (buah) Zaitun, dan demi bukit Sinai, dan demi kota (Mekah) ini yang

${ }^{8}$ Ali Othman, The Concenpt of Man in Islam in the Writings of El Ghazali, (Cairo: Dar el Maaref, 1980), h. xxi.

${ }^{9}$ Departemen Agama RI, Al Quran dan Terjemahnya, (Jakarta: Intermasa, 1992). aman, sesungguhnya Kami telah menciptakan manusia dalam bentuk yang sebaik-baiknya" ${ }^{\prime 10}$.

Konsep manusia sebagai insan ini selalu dihubungkan dengan sifat psikologisnya atau spiritualnya. Hal ini mengindikasikan bahwa manusia sebagai mahluk yang berpikir, berilmu, dan yang memikul amanah (lihat, al Ahzab, Q.S. 72). Dengan sifat-sifat ini manusia terus berusaha bergerak maju menuju ke arah kesempurnaan. Oleh sebab itu, ia sering disebut sebagai "human life" atau "human bicoming".

Adapun manusia yang dinyatakan dengan kalimat "al nas" oleh al Quran disebut dalam salah satu suratnya sebagai berikut: Katakanlah: "Aku berlidung kepada Tuhan (yang memelihara dan menguasai) manusia; Raja manusia; Sembahan manusia; Dari kejahatan (bisikan) syaitan yang biasa bersembunyi; Yang membisikkan (kejahatan) ke dalam dada manusia; Dari (golongan) jin dan manusia" 11 .

Konsep manusia dari al nas ini mengindikasikan manusia sebagai mahluk kolektif atau mahluk sosial. Pada posisi seperti ini, manusia sering disebut sebagai "human sociaty". Dengan demikian, maka al Quran menyebut manusia itu dengan tiga kategori: sebagai mahluk biologis, psikologis, dan sosial. Manusia sebagai biologis, ia tunduk secara mutlak kepada taqdir Tuhan, ini tak ubahnya dengan mahluk lain. Sedangkan sebagai insan dan al nas bertalian dengan "tiupan ilahi" atau ruh Tuhan yang memiliki kebebasan untuk tunduk dan menentang taqdir Tuhan.

Dalam pandangan Ibnu Sina, manusia adalah mahluk sosial dan

${ }^{10}$ At Tin, QS. 95: 1 - 4, dalam, Departemen Agama RI, Al Quran dan Terjemahnya, (Jakarta: Intermasa, 1992).

${ }^{11}$ Al Nas, QS. 114: 1 - 6, dalam, Departemen Agama RI, Al Quran dan Terjemahnya, (Jakarta: Intermasa, 1992). 
sekaligus mahluk ekonomi. Sebagai mahluk sosial, ia tidak dapat memenuhi kebutuhan hidupnya tanpa bergaul dan berkumpul dengan manusia lainnya. Sebagai mahluk ekonomi, ia selalu memikirkan masa depannya, terutama yang terkait dengan kebutuhan akan barangbarang guna memenuhi kebutuhan jasmaninya ${ }^{12}$.

Dibandingkan dengan mahluk lain, manusia adalah mahluk paling sempurna. Karena itu, Tuhan memberikan keistimewaan tertentu kepada manusia sehinnga ia menjadi unggul dari pada mahluk lainnya. Al Quran menyebutkan bahwa Tuhan menciptakan manusia dengan sebaik-baik bentuk dan struktur, dan manusia adalah mahluk yang dimuliakan oleh-Nya, seperti firman-Nya: (QS. al Isra',[17]: 70). "Dan sesungguhnya telah Kami muliakan anak-anak Adam, Kami angkut mereka di daratan dan di lautan, Kami beri mereka rezki dari yang baik-baik dan Kami lebihkan mereka dengan kelebihan yang sempurna atas kebanyakan makhluk yang telah Kami ciptakan".

\section{Fungsi Manusia}

Pada saat Tuhan berkehendak untuk menciptakan manusia, terjadi dialog antara Tuhan dan Malaikat. Episode ini seperti yang digambarkan al Quran "Ingatlah ketika Tuhanmu berfirman kepada para malaikat: "Sesungguhnya Aku hendak menjadikan seorang khalifah di muka bumi."mereka berkata: "mengapa Engkau hendak menjadikan (khalifah) di bumi itu orang yang akan membuat kerusakan padanya dan menumpahkan darah, padahal Kami senantiasa bertasbih dengan memuji Engkau dan mensucikan Engkau? "Tuhan

${ }^{12}$ Dawam Raharjo, Pandangan al Quran tentang Manusia, dalam, Yunahar Ilyas, ed., Pendidikan dalam Perspektif al Quran, (Yogyakarta: Pustaka Pelajar, 1999), h. 19. berfirman: "Sesungguhnya aku mengetahui apa yang tidak kamu ketahui. "(QS. Al Baqarah [2]: 30).

Dari dialog di atas dapat dipahami bahwa, manusia diciptakan Tuhan untuk menjadi kahlifah, yaitu wakil Tuhan. Yang dimaksud dengan wakil Tuhan itu bisa dua macam. Pertama, yang diwujudkan dalam jabatan sultan atau kepala negara. Kedua, fungsi manusia itu sendiri di muka bumi, sebagai ciptaan Tuhan yang paling sempurna. $^{13}$ Keadaan manusia yang terakhir ini menjadi "pertimbangan" Tuhan agar manusia mengemban amanah-Nya, yakni memakmurkan bumi. Manusiapun kemudian menerima amanah itu. Sementara mahluk lain tidak menyanggupinya.

Dengan diterimanya amanah (tugas) Tuhan oleh manusia, berarti manusia telah diberikan kepercayaan, kebijakan dan kekuasaan di bumi ini. Dengan demikian, selain sebagai khalifah di bumi manusia juga pemegang amanah Tuhan. Sebagai pemegang amanah apalagi wakil Tuhan, sudah seharusnyalah manusia melakukan kerja keras untuk memakmurkan bumi melalui berbagai bidang keahlian masingmasing, tanpa merusaknya sedikitpun. Dengan kata lain tugas utama manusia dalam perspektif ini sebagai pemegang amanah untuk menciptakan kesejahteraan bagi seluruh umat manusia tanpa dihalangi oleh batas-batas wilayah, suku, ras, kebangsaan, dan agama. Sementara itu, manusia dalam perspektif khalifah (pemimpin) harus mampu:

1. Menunjukkan perhatian atas terpeliharanya keharmonisan dalam organisasi negara bahkan dunia, dan menghindari ketegangan apalagi konflik.

\footnotetext{
${ }^{13}$ Dawan Rahardjo, Ensiklopedi Al Quran: Tafsir Sosial Berdasarkan Konsep-konsep Kunci, (Jakarta: Paramadina, 2002), 346.
} 
2. Menunjukkan pengertian dan rasa hormat pada kebutuhan-kebutuhan, tujuan-tujuan, keinginan-keinginan, perasaan dan ide-ide yang berkembang dalam masyarakat.

3. Mengadakan komunikasi dengan berbagai pihak, tanpa mempedulikan adanya kelas-kelas tertentu dalam masyarakat.

4. Menekankan prinsip selalu meningkatkan prestasi.

5. Mendorong tumbuhnya inisiasi, inovasi dan kreasi.

6. Menciptakan suatu suasana yang sinergis antar berbagai kalangan.

Selain sebagai khalifah dan pemegang amanah, ia juga pengemban tugas dakwah kepada sesama umat manusia. Hal ini difirmankan Tuhan: "Dan hendaklah ada di antara kamu segolongan umat menyeru kepada kebaikan, menyeru kepada yang ma'ruf dan mencegah dari yang munkar ${ }^{14}$, merekalah orang-orang yang beruntung". (QS. Ali Imran [3]: 104).

Pengetahuan yang dimiliki seseorang, bahkan kemampuannya mengamalkan sesuatu akan berkurang, bahkan mungkin terlupakan dan hilang, jika tidak ada yang mengingatkannya (melalui dakwah). Di sisi lain, pengetahuan dan pengamalan saling berkaitan erat. Pengetahuan mendorong kepada pengamalan dan meningkatkan kualitas amal, sedangkan pengamalan yang terlihat dalam kenyataan hidup merupakan guru yang mengajar individu dan masyarakat sehingga merekapun belajar mengamalkannya. Dengan demikian, maka manusia dan masyarakat perlu selalu diingatkan dan diberi keteladanan. Inilah inti dakwah islamiyah ${ }^{15}$.

\footnotetext{
${ }^{14} \mathrm{Ma}$ 'ruf adalah segala perbuatan yang dapat mendekatkan diri kepada Tuhan, sedangkan munkar adalah segala perbuatan yang dapat menjauhkan diri dari-Nya.

${ }^{15}$ M. Quraish Shihab, Membumikan Al Quran, (Jakarta: Mizan, 2002), h. 173.
}

Memang, jika dakwah yang dimaksud adalah dakwah yang sempurna, maka tentu saja tidak semua orang dapat melakukannya. Di sisi lain, kebutuhan masyarakat dewasa ini, menyangkut informasi yang benar di tengah arus informasi, bahkan "perang" informasi yang demikian pesat dengan sajian nilai-nilai baru yang kadang membingungkan, menuntut adanya dakwah yang dilakukan secara terus menerus guna membendung informasi yang mungkin menyesatkan.

Dalam ajaran Islam, manusia juga mempunyai fungsi yang lebih substantif, yaitu, sebagai hamba Allah. Dalam perspektif ini ia harus tunduk, patuh dan taat kepada Allah. Ia mempunyai tugas untuk mengabdi atau menghambakan dirinya kepada Allah, yaitu dengan melakukan keberserahan diri kepada-Nya. "Dan tidak Aku ciptakan jin dan manusia kecuali untuk mengahambakan diri (beribadah)" (QS. Al Dzariyat, [51]: 56).

Dalam kerangka bahwa, Allah sebagai satu-satunya tuhan dan sesembahan manusia, maka tidak selayaknya manusia menghambakan diri kepada apapun dan siapapun, selain kepada-Nya. Jika manusia melakukan sesembahan kepada selain Allah, maka itu berarti telah merendahkan dirinya sebagai manusia, yang juga dapat dikatakan sebagai menyekutukan Tuhan, secara teologis disebut musyrik ${ }^{16}$.

\section{E. Perbedaan Suku dan Kebangssan dalam pendidikan Islam}

Perbedaan kebangsaan atau suku merupakan Kemajemukan yang menunjukkan adanya kebinekaan, variabilitas, keanekaragamaan manusia. Heterogenitas kebangsaan dan kesukuan

\footnotetext{
${ }^{16}$ Musyrik adalah, orang yang menyekutukan Allah dengan sesuatu selain-Nya baik dalam keyakinan, ucapan atau perbuatan. Lihat, Abdul Mudjib (1995 : 232).
} 
dalam al Quran ditunjukan (QS. al Hujurat [49]: 13)." Hai manusia, sesungguhnya Kami menciptakan kamu dari seorang lakilaki dan seorang perempuan dan menjadikan kamu berbangsa-bangsa dan bersuku-suku supaya kamu saling kenalmengenal. Sesungguhnya orang yang paling mulia di antara kamu di sisi Allah ialah orang yang paling taqwa di antara kamu. Sesungguhnya Allah Maha Mengetahui Lagi Maha Mengenal".

Perbedaan suku atau bangsa, masingmasing akan memberikan manfaat manakala saling mengenal (ta'arafu), saling terbuka peluang untuk berkontribusi. Perkenalan itu juga untuk mengambil pelajaran dan pengalaman pihak lain guna meningkatkan ketakwaan kepada Allah SWT yang dampaknya tercermin pada kedamaian dan kesejahteraan hidup duniawi dan kebahagiaan ukhrawi. Seseorang tidak akan dapat saling menarik pelajaran, saling memberi manfaat, dan saling melengkapi, bahkan bekerjasama, tanpa saling kenal-mengenal ${ }^{17}$.

Kemajemukan merupakan kenyataan sekaligus keniscayaan dalam kehidupan di masyarakat. Keragaman merupakan salah satu realitas utama yang dialami masyarakat dan kebudayaan di masa silam, kini dan di waktu-waktu mendatang sebagai fakta. Memang, adakalanya keragaman disikapi secara berbeda. Di satu sisi diterima sebagai fakta yang dapat memperkaya kehidupan bersama, tetapi di sisi lain dianggap sebagai faktor penyulit. Kemajemukan bisa mendatangkan manfaat yang besar, namun bisa juga menjadi pemicu konflik yang dapat merugikan masyarakat itu sendiri jika tidak dikelola dengan baik. (QS. al Rum, [30]: 22). Dan di antara tanda-tanda kekuasaan-Nya ialah menciptakan langit dan bumi dan berlainlainan bahasamu dan warna kulitmu. Sesungguhnya pada yang demikan itu

\footnotetext{
${ }^{17}$ Ibid, h. 163.
}

benar-benar terdapat tanda-tanda bagi orang-orang yang mengetahui.

Menurut Ibnu Katsir, di antara tandatanda kekuasaan-Nya adalah penciptaan langit dan bumi, dalam arti penciptaan langit dengan ketinggiannya, keluasan hamparan atapnya, kecemerlangan bintang-bintangnya yang tetap dan yang beredar. Serta penciptaan bumi dengan kerendahan dan ketebalannya serta beberapa kandungannya seperti bentuk gunung, laut, padang pasir, hewan, dan pepohonan $^{18}$.

Tanda-tanda kekuasaan Allah yang berikutnya adalah perbedaan bahasabahasa yang ada. Ada yang berbahasa Arab, Tartar, Romawi, Perancis, Barbar, Habsyi, Hindi, 'Ajam, Armenia, Kurdi, dan masih banyak lagi. Keseluruhan dari keragaman bahasa tersebut tidak ada yang mengajarkannya kecuali Allah ${ }^{19}$.

Tanda-tanda selanjutnya adalah keragaman warna kulit manusia. Seluruh penduduk Bumi, sejak diciptakannya Adam sampai hari akhir, semuanya memiliki dua mata, dua alis, satu hidung, dua buah pelipis, satu mulut, dan dua pipi. Meskipun demikian, antara satu dengan yang lainnya tidak memiliki kesamaan. Bahkan dibedakan satu sama lain antara jalannya, sikapnya atau pembicaraannya. Baik nyata ataupun tersembunyi yang hanya dapat terlihat jika melalui perenungan.

Menurut Imam al Qurthubi, hal ini jelas terjadi bukan karena air mani maupun perbuatan dari kedua orang tua. Pasti terdapat pelaku atas semua ini, dan dapat dipastikan bahwa pelakunya adalah Allah S.W.T. Hal ini merupakan dalil yang menunjukkan adanya Tuhan Yang Maha

\footnotetext{
${ }^{18}$ Ibn Katsir, 2010. Tafsir Ibnu Katsir, Jilid 7, Edisi Indonesia, (Jakarta: Pustaka Imam As-Syafi'i, 2010). Cetakan kedua, h. 168.

${ }^{19}$ Ibid, h. 169
} 
Mengatur dan Maha Menciptakan..$^{20}$ Dalam pandangan, satu tetes nutfah berisi puluhan juta sel sperma. Setiap sperma membawa setengah DNA pria pada kromosomnya. Setiap sel telur wanita membawa setengah DNA itu. Pada DNA gabungan itulah tercipta cetak biru manusia. Disitu sudah ditentukan "nasib" manusia, sejak warna kulit sampai komposisi otaknya ${ }^{21}$.Dalam Sabda Nabi SAW, Semua Suku Bangsa Sama di hadapan Allah SWT.

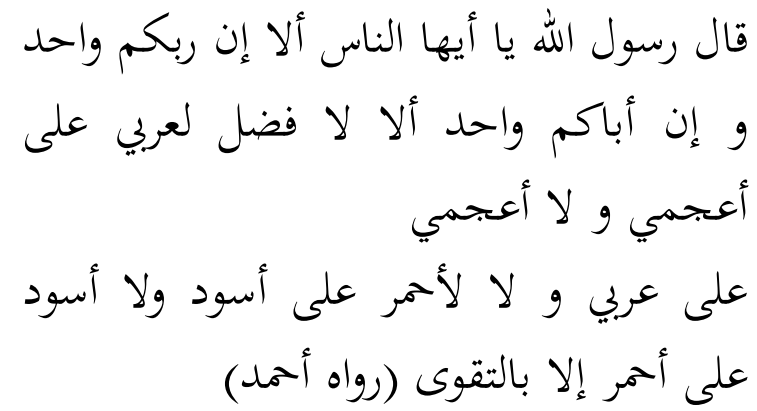

Wahai manusia sekalian, ketahuilah bahwa Tuhan kalian satu, bapak kalian juga satu, ketahuilah tidak ada keutamaan dari orang arab terhadap non arab, dan juga tidak ada keutamaan orang non arab terhadap orang arab, tidak ada keutamaan dari orang berkulit merah terhadap orang berkulit hitam, (demikian pula sebaliknya) tidak ada keutamaan orang yang berkulit hitam terhadap orang yang betkulit merah, kecuali ketakwaannya" (HR. Imam Ahmad). ${ }^{22}$

\section{F. Keterkaitan Manusia dengan Pendidikan}

Manusia adalah mahluk ciptaan Tuhan yang memiliki potensi yang dapat dididik dan mendidik, karenanya ia akan

\footnotetext{
${ }^{20}$ Imam al Qurthubi, Tafsir Al-Qurthubi, Jilid 14, Edisi Indonesia, (Jakarta: Pustaka Azzam, 2009) Cetakan pertama, h. 42.

${ }^{21}$ Alexis Carrel, Man, The Unknown, diterjemahkan oleh Kania Roesli, berjudul, Misteri Manusia, (Bandung: Remaja Karya: 1987), h. viii.

${ }^{22}$ Ahmad bin Ali bin Hajar al-Asqalany, Fath al Bari, Jilid I (Madinah al-Munawarah: 1996 M), Cetakan Pertama, h. 94.
}

mampu menjadi khalifah di bumi, pengembang kebudayaan. Ia dibentuk dengan fitrah Tuhan yang dapat diisi dengan berbagai kecakapan dan berbagai keterampilan yang dapat berkembang, sesuai dengan kedudukannya sebagai mahluk yang mulia. Pikiran, perasaan dan kemampuannya berbuat merupakan komponen dari fitrah itu. Itulash fitrah Allah yang melengkapi penciptaan manusia. "Maka hadapkanlah wajahmu dengan Lurus kepada agama Allah, (tetaplah atas) fitrah Allah yang telah menciptakan manusia menurut fitrah itu. Ttidak ada peubahan pada fitrah Allah. (Itulah) agama yang lurus, tetapi kebanyakan manusia tidak mengetahui" (QS. Ar Rum, [30]: 30).

Secara etimologis, fitrah berasal dari kata fathara (فطر) yang berarti menjadikan. Hasan Langgulung mengartikan fitrah sebagai sebuah potensi yang baik ${ }^{23}$. Nurcholis Madjid dalam bukunya, Islam Doktrin dan Peradaban, mengatakan bahwa manusia menurut asal kejadiannya adalah makhluk fitrah yang suci dan baik, dan karenanya berpembawaan kesucian dan kebaikan. Karena kesucian dan kebaikan itu fitri, maka ia akan membawa rasa aman dan tentram padanya. ${ }^{24}$

Zakiah Daradjat, mengemukakan tentang fitrah dalam ayat di atas, "inilah yang membedakan manusia dengan mahluk Tuhan lainnya, dan fitrah ini pulalah yang menjadikan manusia mulia, dengan kata lain bahwa manusia adalah mahluk paedagogik". 25

\footnotetext{
${ }^{23}$ Hasan Langgulung, Pendidikan dan Peradaban Islam, (Jakarta: Pustaka Al-Husna, 1995), h. 214.

${ }^{24}$ Nurcholis Madjid, Islam Doktrin dan Peradaban, (Jakarta: Yayasan Wakaf Paramadina, 1992), h. 305.

${ }^{25}$ Zakiah Daradjat dkk., Ilmu Pendidikan Islam, (Jakarta: Bumi Aksara, 2009), Cetakan ke delapan, h. 16.
} 
Meskipun demikian, jika potensi itu tidak dikembangkan, niscaya ia kurang bermakna dalam kehidupan. Oleh karena itu perlu dikembangkan, dan pengembangan itu melalui usaha dan kegiatan pendidikan. Pendidikan hendak membawa fitrah manusia kepada tingkatan yang matang. Pendidikan merupakan bagian dari kebudayaan, dalam arti pendidikan merupakan alat untuk menanamkan kemampuan bersikap, bertingkah laku, disamping mengajarkan keterampilan dan ilmu pengetahuan untuk bisa memainkan peranan sosial secara menyeluruh dan sesuai dengan tempat serta kedudukan individu dalam dunia luas. ${ }^{26}$

Filsafat nativis dan impiris telah memperkenalkan teori konvergensi dan membuktikan bahwa manusia adalah mahluk yang dapat dididik dan mendsidik. Dengan pendidikan dan pengajaran potensi itu dapat dikembangkan. Manusia lahir bagaikan kertas putih, bersih belum berisi apa-apa, ia juga dibekali dengan pembawaan yang dapat berkembang sendiri, namun perkembangan itu tidak akan maju jika tidak melalui proses tertentu, yaitu pendidikan ${ }^{27}$. Dalam kaitan ini, pemahaman tentang manusia sangatlah penting, As-Syaibani menyatakan bahwa penentuan sikap dan tanggapan tentang manusia sangat penting dan vital, tanpa sikap dan tanggapan yang jelas, pendidikan akan meraba-raba ${ }^{28}$. Apabila pemahaman tentang manusia tidak jelas, maka berakibat tidak baik pada proses pendidikan itu sendiri.

Dalam konteks filsafat pendidikan Islam, kedudukan manusia sebagaimana posisinya merupakan bagian integral kosmos (alam semesta), maka ia pun tidak

\footnotetext{
${ }^{26}$ Khoiron Rosyadi, Pendidikan Profetik, (Yogyakarta: Pustaka Pelajar, 2004), h. 39.

${ }^{27}$ Zakiah Daradjat, Op. Cit, h. 17.

${ }^{28}$ Omar Muhammad At-Toumi Al-Syaibani, Falsafah Pendidikan Islam, (Jakarta: Bulan Bintang, 1979), h. 10.
}

berbeda jauh dari ruang lingkup kajian ontologi, epistimologi, dan aksiologi yang pada gilirannya menjadi pengukuh bahwa keseluruhannya - tanpa terkecuali manusia - adalah sebagai mahluk ciptaan Tuhan. ${ }^{29}$

Dalam pengembangan potensipotensi nya manusia membutuhkan adanya pihak luar - bantuan - dalam kerangka untuk membimbing, mendorong dan mengarahkan agar berbagai potensi tersebut dapat tumbuh dan berkembang secara wajar dan secara optimal, sehingga kehidupan masa depanya bisa membawa manfaat dan keberhasilan. ${ }^{30} \mathrm{M}$. Arifin berpendapat, bahwa proses pendidikan pada akhirnya berlangsung pada titik kemampuan berkembangnya tiga hal: yaitu mencerdaskan otak yang ada dalam kepala (head), kedua, mendidik akhlak atau moralitas yang berkembang dalam hati (heart), dan ketiga, adalah mendidik kecakapan atau ketrampilan yang pada prinsipnya terletak pada kemampuan tangan ( $h a n d$ ) selanjutnya populer dengan istilah $3 \mathrm{H}^{31}$ Manusia memang makhluk yang misterius, karena ia adalah gabungan antara jasad dan ruh, entitas dipahami sebagai jati diri manusia itu sendiri. Halhal potensial demikian ini tidak menutup kemungkinan pada masa selanjutnya, sasaran pokok proses pendidikan tersebut masih mengalami perubahan. ${ }^{32}$

Dari uraian di atas dapat dipahami bahwa, manusia dan pendidikan adalah bentuk integrasi unik yang tiada padanannya di dunia ini. Dengan bermodal fitrah yang telah dipahami sebagai

\footnotetext{
${ }^{29}$ Jalaluddin, Teologi Pendidikan, (Jakarta: PT GrafindoPersada, 2003), Cetakan ketiga, h. 32.

${ }^{30}$ Zuhairini, dkk., Filsafat Pendidikan Islam, (Jakarta: Bumi Aksara, 1991), h. 94.

${ }^{31}$ H.M. Arifin, Filsafat Pendidikan Islam, Cet., VI, (Jakarta: Remaja Rosdakarya, 2000), h. 57.

${ }^{32}$ Syed M. Naquib Al- Attas, Filsafat dan Praktik Pendidikan Islam, terjemahan. M. Nor Wan Daud, (Bandung: Mizan, 2003), h. 94
} 
kemampuan (potensi) dasar manusia yang berkecenderungan kepada kesucian, kebenaran dan kebaikan (naluri beragama tauhid) merupakan kemampuan dasar yang secara otomatis dapat berkembang serta perlu untuk diarahkan. Maka pada gilirannya dalam proses perkembangan, manusia tertuntut - dipaksa - mau tidak mau harus bergumul dengan pendidikan.

\section{G. Kesimpulan}

Dari uraian di atas dapat diambil kesimpulan bahwa, Islam secara normatif telah menguraikan tentang kesetaraan dalam bermasyarakat yang tidak mendiskriminasikan kelompok lain. Islam memandang segala perbedaan tersebut sebagai sebuah anugrah Tuhan yang begitu besar yang harus di syukuri. Dalam tatanan kehidupan berbangsa dan bernegara masyarakat multikulturalis dalam pandangan Islam memiliki kedudukan yang sama, tidak ada yang merasa paling hebat atau paling kuat dari yang lain. Mereka juga memiliki hak dan kewajiban yang sama baik dalam bidang sosial, politik maupun hukum. Islam mengajarkan suatu konsep bahwa perbedaan seharusnya membuat umat manusia bisa saling melengkapi antara satu umat dan umat lainnya bukan malah menjadi faktor yang menjadi penyebab perselisihan. Agar perbedaan tersebut mendapatkan arahan dan bimbingan secara proporsional, maka pendidikan memegang peranan penting. Pendidikan dapat terlihat dalam perananya sebagai sebuah instrumen untuk menyiapkan generasi demi menunjang peran kemanusiannya di masa yang mendatang. Pendidikan dalam hidup dan kehidupan manusia diakui sebagai satu kesatuan yang sangat penting, hubungan dan interaksi sosial yang terjadi dalam masyarakat, tidak akan bisa berlangsung dengan harmonis jika menegasikan pendidikan sebagai salah satu unsur pokoknya. Tidak dimungkiri pula, bahwa proses pendidikan di masyarakat juga turut mempengaruhi perkembangan kepribadian manusia itu sendiri.

\section{DAFTAR PUSTAKA}

Abdul Azis al Khuli, Mohammad, al Adabun Nabawi, (Beirut: Dar al Fikr, t.t.).

Abdul Baqi, Syaikh, al Mu'jam al Mufahras li Alfadzil Quran, (Kairo: Dar al Hadis al Azhar, 1997)

Agung, Anak, Konseling Lintas Budaya, (Yogyakarta: Graha ilmu 2013).

al Alusi, Shihab al Din, Ruh al Ma'ani, Juz 13, (Beirut: Dar al-Kutub al-Ilmiyah 1993).

Arifin, H.M., Filsafat Pendidikan Islam, Cet., VI, (Jakarta: Remaja Rosdakarya, 2000).

al Qurthubi, Imam, Tafsir Al-Qurthubi, Jilid 14, Edisi Indonesia, (Jakarta: Pustaka Azzam, 2009) Cetakan pertama.

al-Syaibani, Omar Muhammad At-Toumi, Falsafah Pendidikan Islam, (Jakarta: Bulan Bintang, 1979)

Asyarie, Sukmajaya dan Rony Yusyuf, Indek Al Quran, (Bandung: Pustaka, 1999).

al- Attas, Syed M. Naquib, Filsafat dan Praktik Pendidikan Islam, terjemahan. M. Nor Wan Daud, (Bandung: Mizan, 2003).

Basyir, Azhar, Falsafah Ibadah dalam Islam, (Yogayakarta: Pusat UII, 1984).

Carrel, Alexis, Man, The Unknown, diterjemahkan oleh Kania Roesli, berjudul, Misteri Manusia, (Bandung: Remaja Karya: 1987).

Daradjat, Zakiah, dkk., Ilmu Pendidikan Islam, (Jakarta: Bumi Aksara, 2009), Cetakan ke delapan. 
Hadhiri, Choirudin, Klasifikasi Kandungan Al Quran, (Jakarta: Gema Insani Press, 2002).

Hajar al-Asqalany, Ahmad bin Ali bin, Fath al Bari, Jilid I (Madinah alMunawarah: 1996 M).

Jalaluddin, Teologi Pendidikan, (Jakarta: PT GrafindoPersada, 2003), Cetakan ketiga.

Katsir, Ibn, Tafsir al Quran al Azhim, Juz 6, (Beirut: Dar al Fikr, 2000).

Kementerian Agama RI, Al Quran dan Tejemahnya, (Jakarta: Ditjen Bimas Islam, 2012).

Langgulung, Hasan, Pendidikan dan Peradaban Islam, (Jakarta: Pustaka Al-Husna, 1995).

Madjid, Nurcholis, Islam Doktrin dan Peradaban, (Jakarta: Yayasan Wakaf Paramadina, 1992).

Othman, Ali, The Concenpt of Man in Islam in the Writings of El Ghazali, (Cairo: Dar el Maaref, 1980).

Raharjo, Dawam, Ensiklopedi Al Quran: Tafsir Sosial Berdasarkan Konsepkonsep Kunci, (Jakarta: Paramadina, 2002).

--------, Pandangan al Quran tentang Manusia, dalam, Yunahar Ilyas, ed., Pendidikan dalam Perspektif al Quran, (Yogyakarta: Pustaka Pelajar, 1999).

Razak, Yusran dan Tohirin, ed, Pendidikan Agama Islam untuk Perguruan Tinggi dan Umum, (Jakarta: Uhamka Press, 2011).

Shihab, M. Quraish, Membumikan Al Quran, (Jakarta: Mizan, 2002), Cetakan keenam.

--------, Tafsir al Misbah, (Jakarta: Lentera Hati, 2008), Cet. Ke-8.

Rosyadi, Khoiron, Pendidikan Profetik, (Yogyakarta: Pustaka Pelajar, 2004).

Yusuf, M. Yunan, dkk, Aqidah, (Jakarta: IKIP Muhammadiyah, 1999).

Zuhairini, dkk., Filsafat Pendidikan Islam, (Jakarta: Bumi Aksara, 1991).
Zuhri Qudsy, Saifuddin, Meminjam Sosiologi Pengetahuan Peter L. Berger Untuk Studi Hadis, Materi perkuliahan, "Hadis Sosial Ilmu AlQur'an dan Tafsir", Naskah tidak diterbitkkan, Universitas Islam Negeri Sunan Kalijaga Yogyakarta, dalam, 
Keragaman Manusia dalam Pendidikan Islam

Rausyan Fikr. Vol. 16 No. 1 Maret 2020. ISSN. 1979-0074 e-ISSN. 9772580594187 | 67 